\title{
Vasopressin Receptor
}

National Cancer Institute

\section{Source}

National Cancer Institute. Vasopressin Receptor. NCI Thesaurus. Code C17345.

The biologic effects of arg inine vasopressin (AVP) are mediated by 3 receptor subtypes: the V1A and V1B receptors that activate phospholipases via G alpha ( $q / 11)$, and the V2 receptor that activates adenylyl cyclase by interacting with $\mathrm{G}$ alpha (s). This subfamily of G-protein coupled receptors also includes OXT receptors. Their activity is mediated by G proteins which stimulate a phosphatidylinositol-calcium second messenger system. All are involved in the control of body fluid osmolality, blood volume, blood pressure, and vascular tone. (from OMIM) 